\title{
TAX MANEUVER IN RUSSIA'S OIL SECTOR
}

\author{
Yu.Bobylev
}

In 2015, the oil sector was subject to the so called "tax maneuver", a system of measures aimed at significant reduction of economic component of the export duties and increasing the base rate of the mineral extraction tax. Tax maneuver will result in a more efficient structure of the tax system, reduction of subsidizing scale of crude oil refining sector and other EEU member states, provision of more incentives for energy efficient growth. Data released for $\mathrm{H} 1$ 2015, demonstrate significant changes in a number of trends taking place in the oil sector under the effect of the maneuver including reduction of fuel oil production which took place for the first time over the last years and increase of the crude oil exports which is more efficient for the state budget in comparison with fuel oil exports.

2015 saw the kick of the structural reform of the crude oil sector tax regime which envisages a considerable reduction of currents rates of export duty on crude oil and petroleum products while increasing the base rate of the mineral extraction tax (MET) ${ }^{1}$. This reform was defined as "tax maneuver" whose parameters for 2015-2017 were adopted by the Federal Law of 24.11.2014 №366-FZ "«On Amendments to Part II of the Russian Tax Code and Certain Legal Acts of the Russian Federation." In compliance with the law, the base rate of MET on crude extraction increases gradually from Rb493 per ton in 2014 to Rb919 per ton in 2017. While marginal rate of customs duty on crude (coefficient in the formula of calculation of marginal rate) falls from 59\% in 2014 to $30 \%$ in 2017 (Table 1). Simultaneously, export duty rate goes up on "heavy" petroleum products (to $100 \%$ of the export duty rate of crude oil in 2017) and export duty rates on light petroleum products decrease (to $30 \%$ of the export duty rate on crude oil). In order to slow down growth of domestic prices on petroleum products due to the reduction of export duties, the reduction of excises is envisaged.

As a result of the implementation of tax maneuver in comparison with the tax regime of 2014, the MET rate in 2015 up 55\%, in 2017 up 86\%, while the export duty rate on crude oil within price range $\$ 60-100$ per

1 Principal conceptual provisions of this reform were developed at the Gaidar Institute, RANEPA and RFTA and upgraded while drafting socio-economic strategy of Russia for the period to 2020. See: Bobylev Yu.N., Idrisov G.I., Sinelnikov-Murylev S.G. Eksportnye poshliny na neft I nefteprodukty: neobkhodomost otmeny I stenarny analiz posledstvy. [Export Duties on Crude Oil and Petroleum Products: the Need to Abolish and Scenario Analysis of the Outcome]. Moscow, Gaidar Institute Publishers, 2012; Strategia 2020: Novaya model rosta - novaya sotsialnaya politika. [Strategy 2020: New Growth Model - New Social Policy New. Final report of the results of expert work on urgent issues of socio-economic strategy of Russia for the period to 2020.] Book 1. Editors: V.A. Mau, Ya. I. Kuzminov. Moscow, Delo Publishers, RANEPA, 2013. barrel decreases in 2015 by 24-26\%, and in 2017 down 41-45\% (Table 2).

Table 1

TAX RATES IN THE OIL SECTOR IN 2014-2017

\begin{tabular}{|c|c|c|c|c|}
\hline & 2014 & 2015 & 2016 & 2017 \\
\hline $\begin{array}{l}\text { MET on oil extrac- } \\
\text { tion: base rate, } \mathrm{Rb} / \mathrm{t}\end{array}$ & 493 & 766 & 857 & 919 \\
\hline $\begin{array}{l}\text { Crude oil export duty: coef- } \\
\text { ficient in the formula for } \\
\text { calculation of export duty }\end{array}$ & 0.59 & 0.42 & 0.36 & 0.30 \\
\hline \multicolumn{5}{|c|}{$\begin{array}{l}\text { Export duty on petroleum products: } \\
\text { coefficients to the crude oil export duty }\end{array}$} \\
\hline Petrol & 0.90 & 0.78 & 0.61 & 0.30 \\
\hline Diesel fuel & 0.65 & 0.48 & 0.40 & 0.30 \\
\hline Fuel oil & 0.66 & 0.76 & 0.82 & 1.00 \\
\hline \multicolumn{5}{|c|}{ Excises on automobile petrol: } \\
\hline class 4 & 9916 & 7300 & 7530 & 5830 \\
\hline class 5 & 6450 & 5530 & 7530 & 5830 \\
\hline
\end{tabular}

Sources: RF Tax Code, RF Law "On Customs Tariff”, Federal Law of 24.11.2014 №366-FZ.

Table 2

RESTRUCTURING OF TAX RATES ON THE OIL SECTOR AS A RESULT OF TAX MANEUVER COMPARED WITH THE TAX REGIME OF 2014, \%

\begin{tabular}{|l|c|c|c|c|}
\hline & 2015 & \multicolumn{3}{|c|}{2017} \\
\hline $\begin{array}{l}\text { Price of Urals crude, } \\
\text { USD/bbl. }\end{array}$ & 60 & 60 & 80 & 100 \\
\hline \begin{tabular}{l|c|c|c|} 
MET \\
Export duty of crude
\end{tabular} & -24.4 & 86.4 & 86.4 & 86.4 \\
\hline \begin{tabular}{l|l|l|} 
Export duty on petrol \\
Excise on petrol:
\end{tabular} & -34.3 & -80.4 & -81.3 & -81.7 \\
\hline $\begin{array}{l}\text { grade 4 } \\
\text { grade 5 }\end{array}$ & -26.4 & -41.2 & -41.2 & -41.2 \\
\hline
\end{tabular}

Sources: RF Tax Code, RF Law "On Customs Tariff", Federal Law of 24.11.2014 №366-FZ, own calculations.

The need to restructure the oil sector tax regime is determined by a number of factors. Effective until recently the export duty regime ensured subsidizing of the inefficient Russian downstream segment, 
preserved its low technological level and stimulated export of heavy petroleum products. As a result, a number of stable trends were formed which consisted of reduction of crude oil exports, growth of its refining and marketing of the main part of additionally produced petroleum products for exports. Meanwhile, the oil conversion ratio remained very low, and the major part in the export of petroleum products constituted fuel oil which is petroleum product of lower value and is cheaper than crude oil ${ }^{1}$. As a result, in the downstream segment the share of export products over the recent years reached $56 \%$, in other words, it became more export oriented than the upstream segment, whose export share fell to $42.4 \%$. Reduction of export duty rates will cut subsidies to the downstream segment which will create real incentives for its modernization and growth of the oil conversion ratio.

Important factor which determined the need for restructuring the tax regime lies in the fact that the current export duty regime actually ensures subsidizing by Russia of the EEU member states. Export duty is not charged on oil and petroleum products exported to EEU. Reduction of these subsidies seems an economic necessity.

One should point out the excessive role played by the export duty rates in the crude oil tax regime. In the current tax regime, precisely export duty represents the principal tax in the crude oil sector. In 2014, in the structure of crude export price under the standard tax rates the value of the export duty constituted nearly $50 \%$ and twofold exceeded the MET value.

High level of crude export duty leads to the need to regulate the efficient rate of this tax (set for certain oil deposits lower duty rates and the life span of their application) in order to bringing tax burden in line with actual condition of oil extraction, in other words, to give the export duty functions which the MET should perform. The MET can not fully perform its regulating function due to dominance of the export duty.

Reduction of the export duty on crude oil and petroleum products to the point of elimination corresponds to the principles of rent taxation and international practice. Increase of domestic prices on oil and petroleum products and their approximation to the international level as a result of reduction of export duties will create correct price targets for market agents and will enhance incentives to increase energy efficiency.

The feature of the current stage of tax maneuver is the fact that its parameters were developed in 2014 while the oil prices were high and when adopted for calculation of the federal budget revenues for 2015 the oil price stood at $\$ 100$ per barrel. In this context,

1 In Europe, Russian fuel oil is used as material for further refining and production of light oil products. certain reduction of tax burden on crude oil extraction should have taken place which to a certain degree compensated the refinery margin fall for the vertically integrated oil companies. At present, however, implementation of tax maneuver is carried out at a price below the projected one. In the context of low oil prices at the current tax rates the tax burden on the oil extraction goes up which makes companies propose initiatives aimed at revision of the tax maneuver parameters.

However, as calculations demonstrate, at the current oil prices actual increase of tax burden in comparison with the effective tax regime is relatively insignificant. For example, at the oil price of $\$ 60$ per barrel in comparison with 2014 tax regime, the tax burden goes up only by $\$ 0.5$ per barrel or by $0.8 \%$ against the oil price. Surely, the tax maneuver parameters set for 2017 at the price of oil at $\$ 60$ per barrel and over ensure reduction of the tax burden against the 2014 level (Table 3).

As a result of the tax maneuver implementation, a significant adjustment of the tax burden will happen: the share of MET in the rent taxes on the crude oil sector will noticeably increase, and the export customs duties will sharply fall. According to our calculations, at the oil price from $\$ 60$ to $\$ 100$ per barrel, that share of export duty in the oil price will go down from $41-48 \%$ in 2014 to $31-36 \%$ in 2015 and $24-27 \%$ in 2017 (Table 4). Thus, the MET will become the main rent tax and will perform principal functions of the tax regulation in the oil sector. Reduction of the economic role of export duties (up to their elimination) beyond 2017, in our opinion, should be continued.

Figures for H1 2015 demonstrate transformation of a number of trends under the influence of tax maneuver (Table 5). Among them, in our opinion, should be outlined, first, decline of fuel oil production happened for the first time over last years, second, increase of crude oil exports also happened for the first time over last years (for the state budget this type of export is more efficient against export of fuel oil), third, fall of the volume of crude oil refining which is explained by the first two factors. These results, in our opinion, should be viewed as the first outcome of tax maneuver.

At the same time, it should be noted that at this stage tax maneuver did not provoke price hike of motor gasoline on the domestic market. In H1 2015, consumer price growth on motor gasoline AИ-95 and diesel fuel constitute less than $1 \%$, and the price on regular unleaded gasoline (АИ-92) in June was below the level of the last year (Table 6). Factors which limited domestic price growth on motor gasoline were, first, reduction of excises on petroleum products 
Table 3

RESTRUCTURING OF THE TAX BURDEN ON THE OIL PRODUCTION RESULTING FROM TAX MANEUVER

\begin{tabular}{|c|c|c|c|c|c|c|c|}
\hline & \multicolumn{7}{|c|}{ Price of Urals, USD/bbl. } \\
\hline & 50 & 60 & 70 & 80 & 90 & 100 & 110 \\
\hline \multicolumn{8}{|c|}{2014} \\
\hline MET, USD/bbl. & 9.06 & 11.64 & 14.23 & 16.82 & 19.41 & 21.99 & 24.58 \\
\hline Export duties (ED), USD/bbl. & 18.75 & 24.65 & 30.55 & 36.45 & 42.35 & 48.25 & 54.15 \\
\hline MET+ED, USD/bbl. & 27.81 & 36.29 & 44.78 & 53.27 & 61.76 & 70.24 & 78.73 \\
\hline (MET+ED) in \% to price of Urals & 55.62 & 60.48 & 63.97 & 66.59 & 68.62 & 70.24 & 71.57 \\
\hline \multicolumn{8}{|c|}{2015} \\
\hline MET, USD/bbl. & 14.07 & 18.09 & 22.11 & 26.13 & 30.15 & 34.17 & 38.19 \\
\hline ED, USD/bbl. & 14.50 & 18.70 & 22.90 & 27.10 & 31.30 & 35.50 & 39.70 \\
\hline MET+ED, USD/bbl. & 28.57 & 36.79 & 45.01 & 53.23 & 61.45 & 69.67 & 77.89 \\
\hline (MET+ED) in \% to price of Urals & 57.14 & 61.32 & 64.30 & 66.54 & 68.28 & 69.67 & 70.81 \\
\hline Change of tax burden against 2014, USD/bbl. & 0.76 & 0.50 & 0.23 & -0.04 & -0.31 & -0.57 & -0.84 \\
\hline $\begin{array}{l}\text { Change of tax burden against } \\
2014 \text {, in \% to price of Urals }\end{array}$ & 1.52 & 0.83 & 0.33 & -0.05 & -0.34 & -0.57 & -0.76 \\
\hline \multicolumn{8}{|l|}{$\mathrm{x}$} \\
\hline MET, USD/bbl. & 16.88 & 21.71 & 26.53 & 31.35 & 36.18 & 40.99 & 45.82 \\
\hline ED, USD/bbl. & 11.50 & 14.50 & 17.50 & 20.50 & 23.50 & 26.50 & 29.50 \\
\hline MET+ED, USD/bbl. & 28.38 & 36.21 & 44.03 & 51.85 & 59.68 & 67.49 & 75.32 \\
\hline (MET+ED) in \% to price of Urals & 56.76 & 60.35 & 62.90 & 64.81 & 66.31 & 67.49 & 68.47 \\
\hline Change of tax burden against 2014, USD/bbl. & 0.57 & -0.08 & -0.75 & -1.42 & -2.08 & -2.75 & -3.41 \\
\hline $\begin{array}{l}\text { Change of tax burden against } \\
2014 \text {, in \% to price of Urals }\end{array}$ & 1.14 & -0.13 & -1.07 & -1.78 & -2.31 & -2.75 & -3.10 \\
\hline
\end{tabular}

Source: own calculations.

RESTRUCTURING OF THE TAX BURDEN ON THE OIL PRODUCTION RESULTING FROM TAX MANEUVER

\begin{tabular}{|c|c|c|c|c|c|c|c|}
\hline & \multicolumn{7}{|c|}{ Price of Urals, USD/bbl. } \\
\hline & 50 & 60 & 70 & 80 & 90 & 100 & 110 \\
\hline \multicolumn{8}{|c|}{2014} \\
\hline (MET+ED) in \% to price of Urals & 55.62 & 60.48 & 63.97 & 66.59 & 68.62 & 70.24 & 71.57 \\
\hline MET in \% to price of Urals & 18.12 & 19.40 & 20.33 & 21.03 & 21.57 & 21.99 & 22.35 \\
\hline ED in \% to price of Urals & 37.5 & 41.08 & 43.64 & 45.56 & 47.06 & 48.25 & 49.23 \\
\hline \multicolumn{8}{|c|}{2015} \\
\hline (MET+ED) in \% to price of Urals & 57.14 & 61.32 & 64.30 & 66.54 & 68.28 & 69.67 & 70.81 \\
\hline MET in \% to price of Urals & 28.14 & 30.15 & 31.59 & 32.66 & 33.50 & 34.17 & 34.72 \\
\hline ED in $\%$ to price of Urals & 29.00 & 31.17 & 32.71 & 33.88 & 34.78 & 35.50 & 36.09 \\
\hline \multicolumn{8}{|c|}{2017} \\
\hline$(\mathrm{MET}+\mathrm{ED})$ in $\%$ to price of Urals & 56.76 & 60.35 & 62.90 & 64.81 & 66.31 & 67.49 & 68.47 \\
\hline MET in \% to price of Urals & 33.76 & 36.18 & 37.90 & 39.19 & 40.20 & 40.99 & 41.65 \\
\hline ED in \% to price of Urals & 23.00 & 24.17 & 25.00 & 25.63 & 26.11 & 26.50 & 26.82 \\
\hline
\end{tabular}

Source: own calculations.

Table 5

PRODUCTION AND EXPORTS OF OIL AND PETROLEUM PRODUCTS IN 2012-2015, IN \% TO THE CORRESPONDING PERIOD OF THE PREVIOUS YEAR

\begin{tabular}{|l|c|c|c|c|}
\hline & 2012 & 2013 & 2014 & H1 2015 \\
\hline Oil production, including gas condensate & 101.3 & 100.9 & 100.7 & 101.3 \\
\hline Oil export & 98.2 & 98.6 & 94.4 & 106.8 \\
\hline Primary crude oil processing & 104.9 & 102.7 & 104.9 & 98.2 \\
\hline Production of motor gasoline & 104.3 & 101.3 & 98.8 & 102.8 \\
\hline Production of diesel fuel & 98.7 & 103.1 & 107.4 & 99.0 \\
\hline Production of fuel oil & 101.6 & 103.3 & 102.0 & 95.2 \\
\hline
\end{tabular}

Sources: Rosstat, Ministry of Energy of Russia. 
Table 6 implemented within tax maneuver, second, reduction

CONSUMER PRICES OF MOTOR GASOLINE, RB/L

\begin{tabular}{|l|c|c|c|c|}
\hline & $\begin{array}{c}2014 \\
\text { Dec }\end{array}$ & $\begin{array}{c}2015 \\
\text { Jan }\end{array}$ & $\begin{array}{c}2015 \\
\text { Mar }\end{array}$ & $\begin{array}{c}2015 \\
\text { Jun }\end{array}$ \\
\hline Motor gasoline АИ-92 & 33.41 & 32.35 & 32.12 & 32.52 \\
\hline Motor gasoline АИ-95 & 35.21 & 35.16 & 35.00 & 35.34 \\
\hline Diesel fuel & 34.44 & 34.46 & 34.22 & 34.52 \\
\hline
\end{tabular}

Source: Rosstat. of world oil prices which determined decline of netback price of producers.

Thus, H1 2015 results demonstrate retention of rather stable state in the upstream segment and significant transformation in a number of trends in the downstream segment and exports which should be viewed as the first outcome of tax maneuver. 